\title{
MEMBUMIKAN MULTIKULTURALISME SEBAGAI UPAYA PENCEGAHAN SIKAP RADIKALISME BERAGAMA
}

\author{
Ramdanil Mubarok \\ Universitas Islam Malang \\ E-mail: danil.education@gmail.com \\ Maskuri Bakri \\ Universitas Islam Malang \\ E-mail: masykuri@unisma.ac.id
}

\begin{tabular}{|c|c|c|}
\hline Received & Revised & Accepted \\
\hline 4 July 2021 & 2 Agustus 2021 & 20 September 2021 \\
\hline
\end{tabular}

\section{GROUNDING MULTICULTURALISM AS A PREVENTION EFFORT ATTITUDE OF RELIGIOUS RADICALISM}

\begin{abstract}
Accepting other people and other groups regardless of gender, ethnicity, culture, gender and even religion is a concept proposed in multiculturalism. This article will analyze and provide an interpretation of the characteristics of radicalism, efforts to prevent it, and grounding multiculturalism so that it can be an additional insight and experience in the survival of the nation and state. The approach used in this article is a qualitative approach. The type is the type of library research. The result is that radicalism is not only in the form of violence, anarchism, and terrorism but can also be a religious ideology. Efforts to prevent radicalism can be done by building different narratives about radicalism, paying attention to the characteristics of a culture, as well as real social action by planning, implementing, monitoring, and evaluating. Grounding multiculturalism cannot be separated from the life of religion, nation, state and cultural inheritance so that it needs to be studied, applied, and socialized.
\end{abstract}

Keywords: multiculturalism, radicalism, and religion.

\begin{abstract}
Abstrak
Menerima orang lain maupun kelompok lain tanpa memandang perbedaan gender, etnis, suku, budaya, gender bahkan agama merupakan konsep yang diajukan dalam multikulturalisme. Artikel ini akan menganalisis serta memberikan interpretasi tentang karakteristik radikalisme, upaya pencegahannya, serta membumikan multikulturalisme sehingga dapat menjadi tambahan wawasan serta pengalaman dalam kelangsungan kehidupan berbangsa dan bernegara. Pendekatan yang digunakan dalam artikel ini adalah pendekatan kualitatif, adapun jenisnya adalah jenis penelitian kepustakaan. Hasilnya adalah
\end{abstract}


bahwa radikalisme tidak hanya berupa kekerasan, anarkisme, dan terorisme namun bisa juga sebagai paham keagamaan. Upaya untuk mencegah radikalisme dapat dilakukan dengan cara membangun narasi yang berbeda mengenai radikalisme, memperhatikan ciri khas dari suatu budaya, serta aksi sosial yang nyata dengan perencanaan, pelaksanaan, pengawasan, dan evaluasi. Membumikan multikulturalisme tidak dapat dipisahkan dari kehidupan beragama, berbangsa, bernegara dan pewarisan budaya sehingga perlu dipelajari, diterapkan, dan disosialisasikan.

Keywords: multikultural, radikalisme, dan agama.

\section{Pendahuluan}

Kekerasan yang didasari agama masih sering dijumpai di Nusantara ini. Hal tersebut seolah-seolah sejalan dengan demokrasi di Indonesia. Kekerasan-kekerasan tersebut seakan akan melampaui kekerasan ekonomis maupun konflik dan bentrokan antara masyarakat dan penguasa yang disebabkan ketidakberpihakan kebijakan politik tertentu. Beberapa data kekerasan disinyalir terjadi atas nama agama setelah pemilu 2004 yang berhasil dipublikasikan Majalah Gatra pada tahun 2006 diantaranya konflik poso, sekolah Sang Timur yang ditutup oleh FPI, pembelaan aktivitas pluralism yang diintimidasi dan diultimatum, perkampungan jemaat Ahmadiyah yang diserbu di Lombok Barat dan tempat ibadah lainnya.

Terdapat pula konflik antar kelompok sosial, seperti konflik antar suku yang terjadi antara Dayak dan Madura, suku asli dan pendatang, ${ }^{1}$ suku Dani dan Moni, ${ }^{2}$ Suku pribumi Lampung dan Suku Bali, ${ }^{3}$ Kasus yang telah dipaparkan di atas terjadi dan nyata adanya di tengah kelompok-kelompok budaya di Indonesia yang disebut dengan kekerasan antar suku dengan sentimen etnisnya. Selain sentimen etnisme juga terdapat kekerasan atas nama agama, misalnya konflik Tolikara, ${ }^{4}$ (Ridwan) ${ }^{5}$ pembakaran gereja, ${ }^{6}$ konflik SARA, ${ }^{7}$ konflik Situbondo, ${ }^{8}$ serta konflik beragama, ${ }^{9}$ dimana konflik-konflik di atas tidak akan mudah dilupakan sehingga luka itu masih tergores di dalam diri masing-masing kelompok yang berkonflik. Hal tersebut menguatkan asumsi awal bahwa potensi konflik itu ada dalam beragama, walaupun

\footnotetext{
${ }^{1}$ Imam Mustofa, "Peran Organisasi Masyarakat Dalam Membangun Harmoni Pasca Konflik Antara Masyarakat Pribumi Dengan Masyarakat Pendatang Di Lampung Tengah," Penamas 31, no. 1 (2018): 205-26.

${ }^{2}$ Nusen Wenda, Johannis Kaawoan, and Neni Kumayas, "Peran Kepala Suku Dani Dalam Menyelesaikan Konflik Di Kampung Wulukubun Arso 14 Distrik Skanto Kabupaten Keerom Provinsi Papua,” JURNAL EKSEKUTIF 1, no. 1 (2017).

${ }^{3}$ Eva Achjani Zulfa, “Bali Nuraga-Lampung: Identity Conflict Behind the Policy,” Indonesian J. Int'l L. 11 (2013): 261.

${ }^{4}$ Christiany Juditha, "Peace Journalism in News Tolikara Religion Conflict in Tempo. Co-Jurnalisme Damai Dalam Berita Konflik Agama Tolikara Di Tempo. Co," Jurnal Penelitian Komunikasi Dan Opini Publik 20, no. 2 (2016): 123559.

${ }^{5}$ Ridwan Ridwan, "Seeds of Conflict and Religious Intolerance in Papua: A Preliminary Study on Tolikara Incident 2015," Review of Islam in Southeast Asia 1, no. 1 (2018): 89-109.

${ }^{6}$ Muhammad Ansor, "We Are From the Same Ancestors': Christian-Muslim Relations in Contemporay Aceh Singkil," Al-Albab: Borneo Journal of Religious Studies 3, no. 1 (2013): 3-24.

${ }^{7}$ M Alie Humaedi, "Kegagalan Akulturasi Budaya Dan Isu Agama Dalam Konflik Lampung," Analisa: Journal of Social Science and Religion 21, no. 2 (2014): 149-62.

${ }^{8}$ Retnowati Retnowati, “Agama, Konflik, Dan Integrasi Sosial (Integrasi Sosial Pasca Konflik, Situbondo)," Analisa: Journal of Social Science and Religion 21, no. 2 (2014): 189-200.

${ }^{9}$ Lucien M Van Liere, "Fighting for Jesus on Ambon: Interpreting Religious Representations of Violent Conflict," Exchange 40, no. 4 (2011): 322-35.
} 
disaat yang sama orang yang beragama mempunyai keyakinan bahwa beragama itu membawa perdamaian.

Yang terbaru adalah kasus bom di depan gereja Katedral Makassar yang dilakukan oleh sepasang suami istri, dan begitu juga dengan penyerangan Mabes Polri yang dilakukan oleh seorang milenial yang bernama Zakiah Aini. Ini menunjukkan bahwa kekerasan atas nama agama masih menjadi pekerjaan rumah bagi bangsa Indonesia. Fakta lain menurut Kontras dalam, ${ }^{10}$ mengatakan kekerasan mengatasnamakan agama dalam lima tahun terakhir masih tinggi, hal tersebut berdasarkan laporan soal kekerasan yang mereka terima. Kontras merinci bahwa pelaku kekerasan atas nama agama dilakukan oleh masyarakat sipil sebanyak 163 kasus. Kemudian pemerintah 177 kasus, Ormas 148 kasus, dan polisi 92 Kasus.

Jika menelisik ke belakang bahwa multikulturalisme mulai digaungkan ketika mantan menteri agama RI Mukti Ali merumuskan konsep pembinaan kerukunan hidup beragama di Indonesia. Yang mana konsep tersebut dikenal dengan konsep trilogi keyakinan. ${ }^{11}$ Jika didiskusikan tentang kerukunan internal umat beragama akan menghasilkan paparan tentang upaya yang dilakukan masyarakat berkaitan dengan gerakan, pemikiran, dan peran sosial demi kepentingan agama dan bangsa. Demikian juga dengan kerukunan antar umat beragama yang mendialogkan kelompok masyarakat yang berbeda agama mulai dari Islam, Budha, Hindu, Katolik, kristen dan agama serta aliran kepercayaan yang lain.

Bhikhu Parekh mengatakan bahwa multikulturalisme pengakuan akan perbedaan kultur dapat menyebabkan seseorang tidak mampu melakukan sesuatu tanpa didukung oleh adanya hak-hak perbedaan. ${ }^{12}$ Koentjaraningrat menuliskan bahwa manusia itu adalah makhluk yang paling berkuasa dengan akal dan budinya sehingga mampu mengembangkan berbagai sistem untuk memenuhi kebutuhannya. ${ }^{13}$ Demikian juga menurut Muhammad Tholchah Hasan, yang telah melakukan kajian terhadap pandangan Watson, Fay, Lawrence Blum, menguraikan multikulturalisme yang berhubungan dengan kebudayaan dalam konteks agama, manusia paling berkuasa dan paling menonjol bila dibandingkan dengan makhluk yang lain. ${ }^{14}$

Pendapat yang lain juga diutarakan oleh Emile Durkheim bahwa manusia sangat membutuhkan agama sebagai landasan dasar pedoman hidup dalam kehidupan. ${ }^{15}$ Ia melihat bahwa agama merupakan kebutuhan pokok yang akan selalu ada dalam sejarah panjang yang melekat pada diri manusia. Uraian tersebut diperkuat oleh Zuhairi Misrawi hal yang melekat pada diri manusia itu adalah agama. ${ }^{16}$

Mengekspresikan keyakinan dalam keberagamaan merupakan bentuk pilihanpilihan masyarakat yang terkadang dapat menimbulkan gesekan baik diantara internal agama demikian juga dengan agama lain. Hal ini akan dengan mudah

\footnotetext{
${ }^{10}$ Rizky Suryarandika, "KontraS : Kekerasan Atas Nama Agama Tinggi Di Indonesia," Republika, October 22, 2019, https://www.republika.co.id/berita/pzqlrs320/kontras-kekerasan-atas-nama-agama-tinggi-di-indonesia.

${ }^{11}$ Abdul Muis Thabrani, Pengantar E Dimensi-Dimensi Pendidikan (Jember: STAIN Jember Press, 2013).

${ }^{12}$ Bhikhu Parekh, Rethinking Multiculturalism: Keberagaman Budaya Dan Teori Politik (Yogyakarta: Penerbit Kansiius, 2008).

${ }^{13}$ Koentjaraningrat, Pengantar Ilmu Antropolog,(Introduction to Anthropology) (Jakarta: PT Rineka Cipta, 1990).

${ }^{14}$ Muhammad Tholchah Hasan, Pendidikan Multikultural Sebagai Opsi Penanggulangan Radikalisme (Malang: Lembaga Penerbitan UNISMA, 2016).

${ }^{15}$ Emile Durkheim, The Elementary Forms of The Religious Life, Terjemahan M (Yogyakarta: IRCiSoD, 2011).

${ }^{16}$ Zuhairi Misrawi, Mekkah: Kota Suci, Kekuasaan, Dan Teladan Ibrahim (Jakarta: Penerbit Buku Kompas, 2009).
} 
dihindari apabila masing-masing pihak memiliki cara pandang yang terbuka dan saling memahami. ${ }^{17}$ Dalam konteks keIndonesiaan yang memiliki penduduk yang mempunyai latar belakang agama, etnis, dan bahasa yang sangat beragam. Ada penganut agama Islam, Kristen Protestan, Kristen Katolik, Konghucu, Hindu dan Budha. Demikian juga dengan etnis, dan bahasa.

Data dan fakta yang dipaparkan di atas mengantarkan pada pertanyaan bagaimana karakteristik radikalisme, bagaimana upaya pencegahan radikalisme, dan bagaimana membumikan multikulturalisme?. Artikel ini ditulis dengan tujuan menganalisa serta memberikan interpretasi tentang karakteristik radikalisme, upaya pencegahannya, serta membumikan multikulturalisme itu sendiri sehingga dapat menjadi tambahan wawasan serta pengalaman dalam kelangsungan kehidupan berbangsa dan bernegara.

\section{Metode Penelitian}

Pendekatan yang digunakan dalam artikel ini adalah kualitatif dimana jenis penelitiannya menggunakan jenis penelitian kepustakaan (library research). Kirk dan Miller dalam Lexy J Moleong, ${ }^{18}$ mengatakan bahwa penelitian kualitatif merupakan penelitian yang menitikberatkan pada pengamatan manusia dalam lingkupnya sendiri, dan adanya keterkaitan orang lain dalam istilah dan bahasanya sendiri juga. Kemudian pendekatan kepustakaan merupakan kajian yang mendalam berdasarkan analisa yang merujuk pada bahan kepustakaan yang meliputi tulisan yang dipublikasikan baik dalam bentuk artikel ilmiah, koran, majalah, seminar, dan jurnal.

Sehingga penulis melakukan analisis dan interpretasi sumber-sumber yang tertulis baik itu berupa buku teks, artikel jurnal, atau penelitian lain yang relevan dengan topik yang diangkat. Dengan demikian memungkinkan bagi penulis untuk mendeskripsikan keragaman agama, budaya, etnis, dan juga multikulturalisme serta isu radikalisme. Penulis menganalisis, mengkontekstualisasikan dan bahkan mengkritik sebagian apa yang dirujuk serta dikutip dengan tujuan untuk memperkaya wawasan dan memberikan ide-ide yang berkaitan dengan membumikan multikulturalisme sebagai upaya pencegahan radikalisme di Indonesia.

\section{Hasil dan Pembahasan \\ Karakteristik Radikalisme}

Radikalisme terjadi disebabkan oleh faktor yang tidak ada kaitannya dengan agama memang sangat mungkin terjadi, namun ketika penganutnya mengelak dengan mengatakan jangan mengaitkan radikalisme dengan agama bukanlah perkara yang mudah untuk mengubah pola pikir dan anggapan tersebut. Radikalisme dapat menimbulkan gejolak ditengah lingkungan sosial masyarakat. ${ }^{19}$ Pendidikan agama Islam sebagai media dalam hal ini berperan sebagai wadah

\footnotetext{
${ }^{17}$ Alwi Shihab, Islam Inklusif: Menuju Sikap Terbuka Dalam Beragama, VII (Bandung: Mizan Pustaka, 1999).

${ }^{18}$ Lexy J Moleong, Metode Penelitian Kualitatif Edisi Revisi (Bandung: Remaja Rosdakarya, 2006).

${ }^{19}$ Rizky Eka Mahardika, Muhammad Shaleh Assingkily, and Izzatin Kamala, "Persepsi Mahasiswa Terhadap Radikalisme (Studi Penelitian Deskriptif Di UIN Sunan Kalijaga Yogyakarta),” Risâlah, Jurnal Pendidikan Dan Studi Islam 6, no. 1, March (2020): 1-13, https://doi.org/https://doi.org/10.31943/jurnal_risalah.v6i1,\%2oMarch.123.
} 
penyadaran umat untuk mengembangkan keberagamaan yang multikultural dan pluralis. Multikultural merupakan sikap peduli dan terbiasa dengan adanya perbedaan. ${ }^{20}$ Sementara pendidikan Multikultural merupakan proses dalam hidup yang saling menghormati, toleran akan keragaman budaya, dan tulus salam kehidupan bermasyarakat yang plural. ${ }^{21}$ Sehingga diharapkan dengan adanya pendidikan Islam maka pemahaman keagamaan pemeluknya tentang pentingnya toleran dan multikultural dapat diaplikasikan dengan baik dalam kehidupan. Berbicara mengenai pendidikan Islam kaitannya dengan pemahaman keagamaan bisa didapati tidak hanya sebatas belajar di pesantren atau di bangku perkuliahan, namun pemahaman agama dapat dipelajari dalam kondisi yang lain. ${ }^{22}$

Asal kata Radikal yaitu dari kata "radix" (Yunani) berarti akar. Sedangkan bahasa inggris radical misalnya dimaknai sebagai ekstrim, fundamental, revolusioner, menyeluruh, ultra, dan fanatik. Adapun radicalism dimaknai sebagai doktrin (penganut paham radikal dan ekstrim), ${ }^{23}$ Kalau dalam kamus besar bahasa Indonesia sebagaimana dalam artikelnya Nuh Nuhrison bahwa radikal merupakan suatu pemahaman yang membutuhkan kekerasan dalam mengubah sesuatu. ${ }^{24}$

Radikalisme merupakan upaya sosial yang berbentuk gerakan menolak peraturan yang sah yang diikuti dengan menentang dan menciptakan permusuhan dengan orang-orang yang memiliki jabatan atau kekuasaan dalam sebuah lembaga atau pemerintahan. Radikal juga dapat diartikan sebagai sebuah gejala dengan berbagai motif yang berkembang di tengah masyarakat baik itu sosial, agama, budaya, dan politik yang kemudian diekspresikan dalam bentuk kekerasan, anarkis, ekstrimis, akrobatis sebagai bentuk sebuah penolakan terhadap suatu isu yang berkembang. ${ }^{25}$

Dari beberapa definisi radikal yang telah dipaparkan di atas maka perlu digaris bawahi bahwa radikalisme bukan hanya berupa aksi kekerasan, karena dalam realitas sosial yang selama ini dilihat dan dirasakan bahwa kelompok radikal selalu mencari cara untuk memperjuangkan paham keagamaannya. Jadi pada dasarnya bahwa gerakan radikalis tidak melulu ditandai dengan anarkisme atau terorisme namun menolak pancasila sebagai ideologi angsa juga termasuk dalam kategori radikalisme ${ }^{26}$ bahkan radikalisme juga bisa juga ditandai dengan pemahaman agama golongan kanan.

\footnotetext{
${ }^{20}$ Taryana Taryana, “Orientasi Pendidikan Multikultural Terhadap Minoritas,” Risâlah, Jurnal Pendidikan Dan Studi Islam 4, no. 2, Sept (2018): 44-53, https://doi.org/https://doi.org/10.31943/jurnal_risalah.v4i2.63.

${ }^{21}$ Kurnaengsih Kurnaengsih, "The Urgency of Implementation of Multicultural Education in School in Islamic Education Perspective (Urgensi Implementasi Pendidikan Multikultural Di Sekolah Dalam Perspektif Pendidikan Islam)," Risâlah, Jurnal Pendidikan Dan Studi Islam 5, no. 1, March (2019): 113-24, https://doi.org/https://doi.org/10.31943/jurnal_risalah.v5i1.96.

${ }^{22}$ Ramdanil Mubarok, "Peran Takmir Masjid Dalam Pelaksanaan Pendidikan Islam Di Masjid Darus Sakinah Sangatta Utara," Al-Ishlah: Jurnal Pendidikan Islam 18, no. 2 (2020): 233-48, https://doi.org/10.35905/alishlah.v18i2.1576.

${ }^{23}$ Nur Syam, "Deradikalisasi Agama Melalui Pendidikan," IAIN Sunan Ampel, 2013.

${ }^{24}$ M Nuh Nuhrison, "Faktor-Faktor Penyebab Munculnya Faham Atau Gerakan Islam Radikal Di Indonesia," Jurnal Harmoni 8, no. 30 (2009).

${ }^{25}$ Mohammad Kosim, “Pesantren Dan Wacana Radikalisme," JURNAL KARSA (Terakreditasi No. 8o/DIKTI/Kep/2012) 9, no. 1 (2012): 842-53.

${ }^{26}$ Tutik Hamidah Dzaki Aflah Zamani, “Islam Dan Pancasila Dalam Perdebatan Ormas-Ormas Islam,” Risâlah, Jurnal Pendidikan Dan Studi Islam 7, no. 1 (2021): 28-43,

https://doi.org/https://doi.org/10.31943/jurnal_risalah.v7i1.166.
} 
Merujuk Ahmad Rubaidi, dalam "radikalisme Islam Nandlatul Ulama: Masa Depan Moderatisme Islam di Indonesia” bahwa ciri utama radikalisme antara pertama menjadikan Islam yang mengatur individu, politik ketatanegaraan ini sebagai ideologi yang final. Kedua, mengadopsi nilai Islam Timur Tengah tanpa memperhatikan realita sosial dan politik serta kondisi lokal. Ketiga, terlalu terfokus pada tekstual al-Qur'an dan Hadits, Keempat, menolak ideologi non Timur Tengah, dan terakhir kelompok ini cenderung melawan arus, dan Kelima, berseberangan dengan masyarakat majemuk bahkan dengan pemerintah. ${ }^{27}$

Lebih lanjut gerakan radikalisme sangat meresahkan kehidupan berbangsa dan bernegara karena keinginan untuk mengganti ideologi bangsa, mempunyai gerakan yang militan dan menimbulkan keresahan sosial tanpa kompromi, mengancam eksistensi elit penguasa. Sikap radikalisme yang ditunjukkan oleh kelompokkelompok yang tersebar di Indonesia ini mempunyai latar belakang ideologis keagamaan yang berbeda, dan orientasi ideologis yang berbeda. ${ }^{28}$

Karakteristik dan pemahaman yang radikalisme tersebut memiliki kecenderungan sikap yang ingin merubah ideologi bangsa yang sudah final. Fenomena tersebut masih terjadi sampai beberapa waktu yang lalu dengan berturut turut dibubarkannya organisasi yang erat kaitannya dengan radikalisme. Selanjutnya pada pemahaman Islam mengadopsi nilai Islam Timur Tengah tanpa memperhatikan realita sosial dan politik serta kondisi lokal yang ada di Indonesia juga menjadi benih benih radikalisme. Dan benih radikalisme ini tidak hanya disebar di kalangan masyarakat umum tapi sudah masuk ke sekolah-sekolah. Bahkan merujuk ke artikel Maskuri dkk. ${ }^{29}$ mengatakan bahwa fenomena radikalisme sebagai muara terorisme masih menjadi ancaman serius bagi Indonesia.

\section{Upaya Pencegahan Radikalisme}

Secara epistemologi, multikulturalisme terbentuk dari multi, kultur, dan isme. Dimana multi dipahami sebagai banyak, kultur dipahami sebagai budaya, dan isme dipahami sebagai paham atau aliran ${ }^{30}$. Pendidikan multikultural adalah sebuah jawaban dan respon akan keragaman sebagai wujud persamaan hak setiap individu maupun kelompok secara luas yang mencakup peserta didik, ras, gender, strata sosial, budaya, etnik, dan agama. Multikultural merupakan sebuah sistem dalam pendidikan yang dapat mengamati dan keragaman, menghargai kultur yang berbeda yang dapat mendukung tercapainya tujuan pendidikan ${ }^{31}$

\footnotetext{
${ }^{27}$ Ahmad Rubaidi, Radikalisme Islam, Nahdlatul Ulama E Masa Depan Moderatisme Islam Di Indonesia (Logung Pustaka, 2008).

${ }^{28}$ Maskuri Bakri and Anas Saidi, "Peta Radikalisme Agama Di Indonesia: Analisis Kritis Terhadap Dinamika Politik Mahasiswa Dan Masa Depan Demokrasi Indonesia,” Badan Litbang Dan Diklat Kementerian Agama RI, 2017, https://doi.org/http://repository.unisma.ac.id/handle/123456789/6o.

${ }^{29}$ Jefry Hadi Susilo Ramadan, Maskuri Maskuri, and Mutiara Sari Dewi, “Kepemimpinan Kepala Sekolah Dalam Menangkal Radikalisme Di Sekolah Menengah Pertama Bahrul Maghfiroh Malang," Vicratina: Jurnal Pendidikan Islam 5, no. 8 (2020): 65-71, https://doi.org/http://riset.unisma.ac.id/index.php/fai/article/view/7582.

${ }^{30}$ Imam Bukhori, Membumikan Multikulturalisme, HUMANISTIKA : Jurnal Keislaman, vol. 5, 2019, https://doi.org/10.36835/humanistika.v5i1.40.

${ }^{31}$ Carl A Grant and Agostino Portera, Intercultural and Multicultural Education: Enhancing Global Interconnectedness, vol. 39 (Routledge, 2010).
} 
Konsep pendidikan multikultural sudah menjadi rekomendasi secara global untuk diaplikasikan dalam bernegara secara nyata. Ini merupakan konsep yang diadopsi oleh UNESCO untuk global. Indonesia sendiri berdasarkan rekomendasi tersebut harus berupaya untuk mencegah radikalisme dengan upaya-upaya nyata yaitu dengan menerima nilai kebhinekaan, menerima perbedaan baik perbedaan budaya maupun perbedaan gender dan agama. Dapat pula meneguhkan jati diri sebagai sebuah bangsa degan menguatkan tali persaudaraan baik persaudaraan dalam beragama, persaudaraan dalam bernegara, dan persaudaraan dalam bingkai kemanusiaan. Mampu menyelesaikan konflik dengan aman dan damai tanpa menimbulkan anarkis. Tingkatkan perdamaian untuk memperkuat toleransi.

Upaya pencegahan radikalisme yang dapat dilakukan menurut Dody S Truna dkk, salah satunya adalah dengan cara membangun narasi yang berbeda tentang radikalisme yang selama ini dipahami melalui pendidikan multikultural. ${ }^{32}$ Demikian juga Banks memberikan empat pandangannya mengenai upaya pencegahan radikalisme yaitu melalui pendekatan kontribusi, pendekatan mata pelajaran tambahan, pendekatan transformasi, dan pendekatan aksi sosial. ${ }^{33}$

Kaitannya dengan pendapat Banks di atas maka bisa dilakukan dengan memusatkan perhatian pada hal-hal yang berkaitan dengan ciri khas dari suatu budaya sehingga dapat terhindar dari sikap radikalisme dalam suatu budaya tertentu. Dalam hal tambahan mata pelajaran tertentu sangat tepat untuk dilakukan dalam upaya pencegahan sikap radikalisme yaitu dengan memasukkan pelajaran yang memuat etnik, materi tambahan yang berkaitan dengan budaya tanpa melakukan perubahan-perubahan mendasar dalam segi kurikulum dalam pembelajaran. Dalam hal upaya pencegahan dengan pendekatan transformatif maka kiranya dapat dilakukan dengan menyusun rencana pembelajaran yang memuat konsep dan isu-isu yang sedang berkembang dan terkini yang berkaitan dengan etnik budaya yang ada di Indonesia. Terakhir yaitu dengan pendekatan aksi sosial yang nyata dengan perencanaan, pelaksanaan, pengawasan, dan evaluasi yang nyata guna mencegah sikap radikalisme di lingkungan sekitar.

Kemajemukan dalam aspek beragama seharusnya dapat selalu diupayakan guna meminimalisir radikalisme dan ini juga sejalan dengan program pemerintah dalam kurikulum pendidikan. Dari kurikulum tersebut kemudian muncul konsepkonsep yang melahirkan pluralisme, toleransi, dan kerukunan antar etnis, budaya, dan agama. Dalam kurikulum tersebut juga menghasilkan rumusan-rumusan alternatif guna memecahkan permasalahan sosial, serta permasalahan keberagaman. Dengan demikian maka ini menjadi pelecut semangat untuk mengkaji dan mengembangkan konsep multikulturalisme guna memberikan kontribusi dalam upaya pencegahan radikalisme dan menciptakan kerukunan multi agama. Terlebih lagi di Negara Kesatuan Republik Indonesia yang multikultur dapat menjadi contoh bagi negara lain dalam mengembangkan multikulturalisme sehingga pendampingan, penyuluhan sampai pada penelitian dan publikasi mengenai multikulturalisme

\footnotetext{
${ }^{32}$ Dody S Truna et al., "Pendidikan Multikultural Sebagai Upaya Pencegahan Radikalisme Di Indonesia," Digital Library UIN Sunan Gunung Djati Bandung, 2020.

${ }^{33}$ CAMG Banks JA Banks, Handbook of Research on Multicultural Education (Jossey-Bass San Francisco, CA, 2004).
} 
merupakan upaya konkrit yang bisa dilakukan untuk membumikan multikulturalisme guna mencegah sikap radikalisme di tengah-tengan masyarakat.

Upaya pencegahan radikalisme harus dimulai dari diri sendiri, kemudian berlanjut ke lingkungan keluarga, masyarakat sekitar dan masyarakat umum. Tidak kalah penting dalam pencegahan radikalisme dengan melibatkan peran perempuan dengan 1) berdayakan perempuan dengan memberikan tempat dalam pergaulan sosial 2) atasi ketimpangan struktural dan tidak adilan sosial, 3) pemerataan ekonomi berkelanjutan, 4) pemberdayaan 5) penguatan advokasi hukum, sosial, dan deradikalisasi ideology. ${ }^{34}$

Demikian juga di lingkungan pendidikan, radikalisme harus dicegah sedini mungkin sehingga tidak menjadi bibit-bibit terorisme di masa yang akan datang dengan 1) penguatan kurikulum, 2) budaya religious. 3) kegiatan intrakurikuler, kokurikuler, dan ekstrakurikuler. ${ }^{35}$ Sehingga diperlukan guru pendidikan agama Islam yang multikultural yang mampu menjadi pengajar, pengarah, pembimbing, serta bekerjasama ${ }^{36}$, sehingga memudahkan proses pembelajaran guna mencegah radikalisme sedini mungkin.

\section{Membumikan Multikulturalisme}

Multikultural dalam khazanah keilmuan maka multikultural dibedakan menjadi pluralitas, lebih dari satu, keragaman, dan menunjukkan heterogenitas dan tidak bisa disamakan. Itulah sesungguhnya multikultural. Secara epistemologi, multikulturalisme terbentuk dari multi, kultur, dan isme. Dimana multi dipahami sebagai banyak, kultur dipahami sebagai budaya, dan isme dipahami sebagai paham atau aliran. ${ }^{37}$ Multikulturalisme mengandung pengertian yaitu multi yang berarti plural, dan kultural yang berarti kultur budaya. Dua ciri utama dari multikulturalisme yaitu kebutuhan akan pengakuan dan legitimasi keragaman budaya. $^{38}$ Sebagaimana diungkapkan oleh Hilda Hernandez multikulturalisme adalah kesederajatan, kerjasama, dan mengapresiasi dunia. ${ }^{39}$ Demikian juga Parsudi Suparlan memberikan penekanan kepada individu dan kelompok bahwa mengakui ideologi, serta merawat perbedaan juga merupakan salah satu upaya membumikan multikulturalisme. ${ }^{40}$ Jadi bersedia menerima perbedaan tanpa memandang perbedaan bahasa, etnis, suku, budaya, bahasa, gender, dan agama dengan kelompok lain merupakan inti dari multikulturalisme.

Pendapat yang dikemukakan oleh Parekh bahwa keragaman budaya yang sering dijumpai terbagi pada tiga bentuk yaitu, subcultural diversity, perspectival

\footnotetext{
${ }^{34}$ Umi Sumbulah, “Perempuan Dan Keluarga: Radikalisasi Dan Kontra Radikalisme Di Indonesia," 2019.

${ }^{35}$ Mutiara Sari Dewi Jefry Hadi Susilo Ramadan, Maskuri Maskuri, "Kepemimpinan Kepala Sekolah Dalam Menangkal Radikalisme Di Sekolah Menengah Pertama Bahrul Maghfiroh Malang,” VICRATINA : Jurnal Pendidikan Islam 5, no. 1 (2020): 1-5.

${ }^{36}$ Ramdanil Mubarok Muhaemin, “Upgrade Kompetensi Guru PAI Dalam Merespon Pembelajaran Jarak Jauh Dimasa Pandemi Covid-19,” AL-FIKR: Jurnal Pendidikan Islam 6, no. 2 (2020): 75-82,

https://doi.org/10.32489/alfikr.v6i2.80.

${ }^{37}$ Imam Bukhori, Membumikan Multikulturalisme.

${ }^{38}$ C.W. Waston, Multiculturalism (London: Open University Press, 200o).

${ }^{39}$ Hilda Hernandez, Multicultural Education: A Teacher's Guide to Content and Process (Prentice Hall, 1989).

${ }^{40}$ Parsudi Suparlan, Suku Bangsa Dan Hubungan Antar Suku Bangsa (Jakarta: Grasindo, 2005).
} 
diversity, dan communal diversity. ${ }^{41}$ Ketiga bentuk tersebut kemudian dijelaskan sebagai berikut:

\section{Keanekaragaman Sub-budaya}

Pada point tentang keanekaragaman sub-budaya ini dapat dipahami sebagai kesatuan dalam mengakui dan meyakini kultur budaya namun berbeda dalam mengimplementasikan keyakinannya dan berbeda dalam praktek dalam kehidupan. Contoh sederhananya adalah prostitusi, kaum lesbian dan gay, pekerja sex komersial, atau gaya hidup yang bar bar. Dari contoh tersebut mungkin menurut sebagian orang beranggapan hal tersebut tidak bermoral, tidak lumrah, dan cenderung menyimpang dari budaya ketimuran namun bagi mereka itu adalah jalan dan pilihan hidup mereka serta mereka merasa bahagia dan nyaman dalam menjalani hidup mereka. Mereka menjalankan pola budaya yang cenderung berbeda dengan kebanyakan orang. Pada intinya sama sama meyakini sebuah budaya namun berbeda dalam penerapan individual.

\section{Keanekaragaman Perspektif}

Masyarakat biasanya akan sangat kritis dalam melihat dan menilai sesuatu dari sebuah budaya sehingga akan tercipta keseimbangan. Seperti halnya para pecinta lingkungan akan mengkritisi pandangan manusia kaitannya dengan mengeksploitasi alam, orang kulit hitam akan mengkritisi bias rasisme. Pun dengan kawin lari di suku bugis di Sulawesi Selatan akan mengkritisi budaya kawin lari di suku sasak lombok dimana keduanya sama-sama kawin lari namun berbeda dalam pandangan hukum adat dan budaya setempat.

\section{Keanekaragaman Komunal}

Pada keanekaragaman komunal ini bahwa masyarakat modern yang berada dalam suatu daerah maupun suatu komunitas dan organisasi akan melestarikan keyakinan mereka melalui praktik yang pasti berbeda. Yang termasuk dalam bentuk keanekaragaman komunal ini seperti adanya penduduk asli (pribumi) di sebuah daerah, kelompok imigran yang ada di suatu daerah, atau lebih luas lagi seperti kelompok Basques di Spanyol. Ada juga organisasi budaya yang sudah lama berdiri dan matang dari segi usia organisasi dan kematangan dari segi sumber daya organisasinya. Hal-hal yang demikian itulah yang kemudian dikategorikan dengan keanekaragaman komunal.

Dari ketiga bentuk tersebut apabila suatu masyarakat menganut ketiga bentuk tersebut maka dan adanya keanekaragaman minimal bentuk kedua dan ketiga maka menurut parekh itulah yang disebut dengan masyarakat multikultural. Jadi masyarakat multikultural adalah masyarakat yang minimal menganut dua dari ketiga bentuk keragaman budaya yang dijelaskan sebelumnya. Kemungkinan kemungkinan yang bisa terjadi dalam kemajemukan budaya ini adalah apa yang dikenal dengan kemajemukan yang dipersilahkan dan dirayakan. Dan kebijakan asimilasi dalam budaya dilebur menjadi satu baik secara keseluruhan maupun sebagian.

\footnotetext{
${ }^{41}$ Parekh, Rethinking Multiculturalism: Keberagaman Budaya Dan Teori Politik.
} 
Suatu masyarakat dikatakan multikultural apabila di dalamnya terdapat keanekaragaman dan perbedaan. Dan sejatinya masyarakat Indonesia merupakan masyarakat yang multikultural. Hal tersebut dapat dikuatkan dengan banyaknya budaya, suku, bahasa, agama, adat istiadat, dan bahkan kesenian. Dan keragamankeragaman dalam perbedaan tersebut baik dari segi struktur budaya, perbedaan nilai, ciri fisik, warna kulit, dan perbedaan perbedaan yang lain baik dari segi struktur sosial maupun perbedaan fisik. Maka bangsa Indonesia ketika membahas tentang multikultural sesungguhnya multikultural itu adalah bangsa Indonesia itu sendiri. Multikultural mengajarkan semangat akan keberagaman, semangat persatuan, semangat dalam berbhineka tunggal ika yang akan menjamin persatuan bangsa.

Membumikan multikulturalisme merupakan hal yang perlu dipertegas kembali dengan asumsi bahwa multikulturalisme sebenarnya bukanlah barang yang baru dalam kehidupan. Dalam segala aspek kehidupan multikulturalisme tidak dapat dipisahkan dari kehidupan beragama, berbangsa, bernegara dan pewarisan budaya.

Pewarisan budaya merupakan sebuah pedoman yang akan mengatur segala bentuk perilaku kehidupan bermasyarakat. Dengannya akan mengatur tingkah laku manusia berkaitan dengan dirinya dengan dengan sesama manusia serta dirinya dengan makhluk lain dan lingkungannya. Dengan demikian untuk dapat mewujudkan berbagai macam budaya yang mengatur norma sosial dengan berbagai macam aturannya maka perlu membumikan multikulturalisme di tengah masyarakat. Selanjutnya norma-norma serta aturan dalam budaya tersebut kemudian diwariskan kepada generasi selanjutnya sebagai pegangan dalam kehidupan yang berbudaya.

Memang ketika berbicara tentang pewarisan budaya maka butuh proses yang tidak mudah. Butuh waktu dan proses yang lama untuk dapat mewujudkan pewarisan budaya tersebut karena pada hakikatnya pewarisan budaya beserta nilainilai yang terkandung di dalamnya tidak bisa dilepaskan dari proses pembelajaran. Dan naluri manusia akan menyeleksi berbagai macam unsur budaya tersebut yang sesuai dengan tatanan lingkungan kehidupannya. Dengan demikian maka pewarisan budaya merupakan sebuah proses pembelajaran yang dilaksanakan tulal hayah.

Jika menelisik kehidupan masyarakat modern dan perkotaan maka akan dijumpai berbagai perbedaan yang mendasar dalam pewarisan budaya tersebut karena pada dasarnya manusia akan mengalami proses pembelajaran budaya sesuai dengan zamannya, dan sesuai dengan lingkungannya. Demikian juga dengan masyarakat pedalaman, mereka akan mempelajari budaya dalam konteks lingkungan pedesaan yang cenderung menjadikan lingkungan keluarga sebagai lembaga pendidikan budaya. Orang tua akan menjadi guru pertama dalam proses pembelajaran budaya dengan segala bentuk norma dan aturannya yang mana hal tersebut jarang dijumpai di tatanan kehidupan modern perkotaan yang disebabkan karena orang intensitas pertemuan dan interaksi dengan orang tua yang minim.

Dalam Koentjaraningrat dalam mewarisi budaya perlu melakukan enkulturasi, sosialisasi, dan internalisasi yang akan dijelaskan sebagai berikut. ${ }^{42}$

\footnotetext{
${ }^{42}$ Koentjaraningrat, Pengantar Ilmu Antropolog,(Introduction to Anthropology).
} 
Enkulturasi merupakan proses pembelajaran budaya secara individu serta menyesuaikan pikiran dan sikap dengan adat istiadat, peraturan, dan norma dalam kehidupan. Hal tersebut dapat dilakukan secara tidak langsung proses pewarisan budaya dalam istilah enkulturasi tersebut berlangsung dalam kehidupan sesuai dengan adat dan norma yang berlaku di tengah masyarakat dengan berupaya menyesuaikan diri secara individu. Pada dasarnya proses pewarisan budaya dalam istilah enkulturasi tersebut telah dimulai sejak manusia lahir melalui kehidupan di tengah keluarga dan masyarakat setempat yang diawali dengan meniru dan interaksi dalam pergaulan di tengah masyarakat.

Sosialisasi merupakan sebuah proses pembelajaran budaya yang dikaitkan dengan sistem sosial. Pada proses ini manusia sejak kanak-kanak akan belajar dalam bentuk interaksi dengan orang disekelilingnya, yang selanjutnya akan berproses melalui hubungannya dengan individu lainnya dan akan menduplikasi bagaimana berbudaya dengan menduplikasi generasi sebelumnya. Biasanya proses ini akan sangat berkaitan dengan inkulturasi karena pada akhirnya kepribadian akan terbentuk mengikuti kultur budaya ditengah masyarakat.

Internalisasi merupakan proses penerapan budaya yang dilakukan tulal hayah, dimulai sejak ia lahir sampai ia masuk ke liang lahat. Proses pewarisan budaya dalam internalisasi ini akan terus berproses melalui pengelolaan nafsu, perasaan, serta emosi yang akan berujung pada kepribadian. Sehingga budaya tersebut tercermin dalam sikap dan kepribadian manusia.

Adapun sarana dalam pewarisan budaya yang dapat digunakan kepada generasi selanjutnya antara lain: 1) Sarana Keluarga, 2) Sarana Masyarakat, 3) Sarana Sekolah, 4) Lembaga Pemerintahan, 5) Paguyuban, 6) Institusi Resmi, 7) Media Massa

Setelah pewarisan budaya maka membumikan multikulturalisme juga dapat dilakukan dengan pendidikan yaitu pendidikan multikultural. Multikultural dapat dipahami sebagai keragaman budaya, adapun pendidikan dapat dipahami sebagai sebuah sikap yang berkembang maupun tingkah laku seseorang yang dengan sadar melalui proses pembelajaran dan pelatihan. ${ }^{43}$ Istilah multikultural ini lahir dari hasil pengamatan seorang praktisi pendidikan amerika yang bernama Prudence Crandall. Ia merupakan seorang pakar yang aktif memberikan pandangannya mengenai urgennya melihat aspek budaya, agama, etnis seorang peserta didik. Cikal bakal lahirnya multikulturalisme itu ketika pendidikan memberikan perhatian khusus terhadap latar belakang kehidupan peserta didiknya. ${ }^{44}$

Pendidikan bukanlah sebuah property elite yang dapat menjauhkan realitas budaya sosial sekitarnya, namun pendidikan seharusnya dapat menciptakan masyarakat yang berpendidikan bukan masyarakat yang mengagungkan kekayaan dan strata sosial ${ }^{45}$ Pendidikan multikultural adalah sebuah jawaban dan respon akan keragaman sebagai wujud persamaan hak setiap individu maupun kelompok secara luas yang mencakup peserta didik, ras, gender, strata sosial, budaya, etnik, dan

\footnotetext{
${ }^{43}$ Dody S. Taruna, Pendidikan Islam Berwawasan Multikultural (Jakarta: Kementerian Agama RI, 2010).

${ }^{44}$ Moch Fuad, Pendidikan Islam Dan Tantangan Globalisasi Perspektif Sosial Budaya, Dalam, Pendidikan Islam Dan Tantangan Globalisasi: Buah Pikiran Seputar Filsafat, Politik, Ekonomi, Sosial Dan Budaya (Yogyakarta: Ar Ruzz Media dan Presma Fakultas Tarbiyah UIN Sunan Kalijaga, 2004).

${ }^{45}$ Paulo Freire, Politik Pendidikan: Kebudayaan, Kekuasaan, Dan Pembebasan, ed. Agung Prihantoro, Terj.

(Yogyakarta: Pustaka Pelajar, 2007).
} 
agama. Demikian juga apa yang dikemukakan oleh James A Banks tentang multikultural yaitu pendidikan itu adalah kebebasan dalam rangka mempererat hubungan antar sesama. ${ }^{46}$

Dari segi fokus pendidikan multikultural maka Henry Alexis Rudolf Tilaar dapatlah dijadikan rujukan dengan pendapatnya bahwa pendidikan multikultural bukanlah pendidikan yang diarahkan pada kelompok domain kultural, kelompok sosial, dan agama, sebab pada dasarnya pendidikan multikultural merupakan suatu sikap peduli kepada orang lain dari kelompok minoritas. ${ }^{47}$

Dengan demikian maka pendidikan multikultural merupakan proses pengembangan untuk meningkatkan sesuatu yang sudah ada serta mengembangkan seluruh potensi yang dimiliki manusia mulai dari budaya, ekonomi, intelektual, kesopanan, religius, sosial dan moral yang menghargai pluralitas dan heterogenitas. Maka sangatlah tepat bila membumikan multikulturalisme itu harus dibarengi dengan pendidikan multikultural.

\section{Simpulan}

Radikalisme tidak hanya berupa kekerasan, anarkisme, dan terorisme namun bisa juga sebagai faham keagamaan. Menerima orang lain maupun kelompok lain tanpa memandang perbedaan gender, etnis, suku, budaya, gender bahkan agama merupakan konsep yang diajukan dalam multikulturalisme. Upaya yang bisa dilakukan untuk mencegah radikalisme antara lain dengan dengan cara membangun narasi yang berbeda mengenai radikalisme, memperhatikan ciri khas dari suatu budaya sehingga dapat terhindar dari sikap radikalisme dalam suatu budaya tertentu, melakukan tindakan sosial yang nyata dengan perencanaan yang matang, pelaksanaan yang totalitas, pengawasan yang kontinyu, dan evaluasi yang nyata guna mencegah sikap radikalisme di lingkungan sekitar. Membumikan multikulturalisme tidak dapat dipisahkan dari kehidupan beragama, berbangsa, bernegara dan pewarisan budaya sehingga perlu dipelajari secara individu serta menyesuaikan pikiran dan sikap dengan adat istiadat, peraturan, dan norma dalam kehidupan. Membumikan multikulturalisme dengan pelaksanaan yang terus berproses melalui pengelolaan nafsu, perasaan, serta emosi yang akan berujung pada kepribadian, sehingga budaya tersebut tercermin dalam sikap dan kepribadian manusia. Membumikan multikulturalisme perlu disosialisasikan sehingga terjalinnya hubungan individu dengan individu lainnya, dan terjadinya proses duplikasi dari generasi sebelumnya.

\footnotetext{
${ }^{46}$ James A Banks, Educating Citizens in a Multicultural Society. Multicultural Education Series. (ERIC, 1997).

${ }^{47}$ Henry Alexis Rudolf Tilaar, Pendidikan, Kebudayaan, Dan Masyarakat Madani Indonesia (Bandung: PT. Remaja Rosdakarya, 1999).
} 


\section{DAFTAR PUSTAKA}

Ansor, Muhammad. "We Are From the Same Ancestors': Christian-Muslim Relations in Contemporay Aceh Singkil.” Al-Albab: Borneo Journal of Religious Studies 3, no. 1 (2013): 3-24.

Bakri, Maskuri, and Anas Saidi. "Peta Radikalisme Agama Di Indonesia: Analisis Kritis Terhadap Dinamika Politik Mahasiswa Dan Masa Depan Demokrasi Indonesia." Badan Litbang Dan Diklat Kementerian Agama RI, 2017. https://doi.org/http://repository.unisma.ac.id/handle/123456789/6o.

Banks, James A. Educating Citizens in a Multicultural Society. Multicultural Education Series. ERIC, 1997.

Durkheim, Emile. The Elementary Forms of The Religious Life, Terjemahan M. Yogyakarta: IRCiSoD, 2011.

Dzaki Aflah Zamani, Tutik Hamidah. "Islam Dan Pancasila Dalam Perdebatan Ormas-Ormas Islam.” Risâlah, Jurnal Pendidikan Dan Studi Islam 7, no. 1 (2021): 28-43. https://doi.org/https://doi.org/10.31943/jurnal_risalah.v7i1.166.

Freire, Paulo. Politik Pendidikan: Kebudayaan, Kekuasaan, Dan Pembebasan. Edited by Agung Prihantoro. Terj. Yogyakarta: Pustaka Pelajar, 2007.

Fuad, Moch. Pendidikan Islam Dan Tantangan Globalisasi Perspektif Sosial Budaya, Dalam, Pendidikan Islam Dan Tantangan Globalisasi: Buah Pikiran Seputar Filsafat, Politik, Ekonomi, Sosial Dan Budaya. Yogyakarta: Ar Ruzz Media dan Presma Fakultas Tarbiyah UIN Sunan Kalijaga, 2004.

Grant, Carl A, and Agostino Portera. Intercultural and Multicultural Education: Enhancing Global Interconnectedness. Vol. 39. Routledge, 2010.

Hasan, Muhammad Tholchah. Pendidikan Multikultural Sebagai Opsi Penanggulangan Radikalisme. Malang: Lembaga Penerbitan UNISMA, 2016.

Hernandez, Hilda. Multicultural Education: A Teacher's Guide to Content and Process. Prentice Hall, 1989.

Humaedi, M Alie. "Kegagalan Akulturasi Budaya Dan Isu Agama Dalam Konflik Lampung." Analisa: Journal of Social Science and Religion 21, no. 2 (2014): 149-62.

Imam Bukhori. Membumikan Multikulturalisme. HUMANISTIKA : Jurnal Keislaman. Vol. 5, 2019. https://doi.org/10.36835/humanistika.v5i1.40.

JA Banks, CAMG Banks. Handbook of Research on Multicultural Education. JosseyBass San Francisco, CA, 2004.

Jefry Hadi Susilo Ramadan, Maskuri Maskuri, Mutiara Sari Dewi. "Kepemimpinan Kepala Sekolah Dalam Menangkal Radikalisme Di Sekolah Menengah Pertama Bahrul Maghfiroh Malang." VICRATINA : Jurnal Pendidikan Islam 5, no. 1 (2020): 1-5.

Juditha, Christiany. "Peace Journalism in News Tolikara Religion Conflict in Tempo. Co-Jurnalisme Damai Dalam Berita Konflik Agama Tolikara Di Tempo. Co." Jurnal Penelitian Komunikasi Dan Opini Publik 20, no. 2 (2016): 123559.

Koentjaraningrat. Pengantar Ilmu Antropolog,(Introduction to Anthropology). Jakarta: PT Rineka Cipta, 1990.

Kosim, Mohammad. "Pesantren Dan Wacana Radikalisme." JURNAL KARSA (Terakreditasi No. 8o/DIKTI/Kep/2012) 9, no. 1 (2012): 842-53. 
Kurnaengsih, Kurnaengsih. "The Urgency of Implementation of Multicultural Education in School in Islamic Education Perspective (Urgensi Implementasi Pendidikan Multikultural Di Sekolah Dalam Perspektif Pendidikan Islam).” Risâlah, Jurnal Pendidikan Dan Studi Islam 5, no. 1, March (2019): 113-24. https://doi.org/https://doi.org/10.31943/jurnal_risalah.v5i1.96.

Liere, Lucien M Van. "Fighting for Jesus on Ambon: Interpreting Religious Representations of Violent Conflict.” Exchange 40, no. 4 (2011): 322-35.

Mahardika, Rizky Eka, Muhammad Shaleh Assingkily, and Izzatin Kamala. "Persepsi Mahasiswa Terhadap Radikalisme (Studi Penelitian Deskriptif Di UIN Sunan Kalijaga Yogyakarta)." Risâlah, Jurnal Pendidikan Dan Studi Islam 6, no. 1, March (2020): https://doi.org/https://doi.org/10.31943/jurnal_risalah.v6i1,\%2oMarch.123.

Misrawi, Zuhairi. Mekkah: Kota Suci, Kekuasaan, Dan Teladan Ibrahim. Jakarta: Penerbit Buku Kompas, 2009.

Moleong, Lexy J. Metode Penelitian Kualitatif Edisi Revisi. Bandung: Remaja Rosdakarya, 2006.

Mubarok, Ramdanil. "Peran Takmir Masjid Dalam Pelaksanaan Pendidikan Islam Di Masjid Darus Sakinah Sangatta Utara.” Al-Ishlah: Jurnal Pendidikan Islam 18, no. 2 (2020): 233-48. https://doi.org/10.35905/alishlah.v18i2.1576.

Muhaemin, Ramdanil Mubarok. "Upgrade Kompetensi Guru PAI Dalam Merespon Pembelajaran Jarak Jauh Dimasa Pandemi Covid-19." AL-FIKR: Jurnal Pendidikan Islam 6, no. 2 (2020): 75-82. https://doi.org/10.32489/alfikr.v6i2.8o.

Mustofa, Imam. "Peran Organisasi Masyarakat Dalam Membangun Harmoni Pasca Konflik Antara Masyarakat Pribumi Dengan Masyarakat Pendatang Di Lampung Tengah.” Penamas 31, no. 1 (2018): 205-26.

Nuhrison, M Nuh. "Faktor-Faktor Penyebab Munculnya Faham Atau Gerakan Islam Radikal Di Indonesia." Jurnal Harmoni 8, no. 30 (2009).

Parekh, Bhikhu. Rethinking Multiculturalism: Keberagaman Budaya Dan Teori Politik. Yogyakarta: Penerbit Kansiius, 2008.

Ramadan, Jefry Hadi Susilo, Maskuri Maskuri, and Mutiara Sari Dewi. "Kepemimpinan Kepala Sekolah Dalam Menangkal Radikalisme Di Sekolah Menengah Pertama Bahrul Maghfiroh Malang." Vicratina: Jurnal Pendidikan $\begin{array}{lllll}\text { Islam } & 5, & \text { no. } & 8 & \text { (2020): }\end{array}$ https://doi.org/http://riset.unisma.ac.id/index.php/fai/article/view/7582.

Retnowati, Retnowati. "Agama, Konflik, Dan Integrasi Sosial (Integrasi Sosial Pasca Konflik, Situbondo).” Analisa: Journal of Social Science and Religion 21, no. 2 (2014): 189-200.

Ridwan, Ridwan. "Seeds of Conflict and Religious Intolerance in Papua: A Preliminary Study on Tolikara Incident 2015." Review of Islam in Southeast Asia 1, no. 1 (2018): 89-109.

Rubaidi, Ahmad. Radikalisme Islam, Nahdlatul Ulama E Masa Depan Moderatisme Islam Di Indonesia. Logung Pustaka, 2008.

Shihab, Alwi. Islam Inklusif: Menuju Sikap Terbuka Dalam Beragama. VII. Bandung: Mizan Pustaka, 1999. 
Sumbulah, Umi. "Perempuan Dan Keluarga: Radikalisasi Dan Kontra Radikalisme Di Indonesia," 2019.

Suparlan, Parsudi. Suku Bangsa Dan Hubungan Antar Suku Bangsa. Jakarta: Grasindo, 2005.

Suryarandika, Rizky. "KontraS : Kekerasan Atas Nama Agama Tinggi Di Indonesia." Republika. October 22, 2019. https://www.republika.co.id/berita/pzqlrs32o/kontras-kekerasan-atas-namaagama-tinggi-di-indonesia.

Syam, Nur. "Deradikalisasi Agama Melalui Pendidikan." IAIN Sunan Ampel, 2013.

Taruna, Dody S. Pendidikan Islam Berwawasan Multikultural. Jakarta: Kementerian Agama RI, 2010.

Taryana, Taryana. "Orientasi Pendidikan Multikultural Terhadap Minoritas." Risâlah, Jurnal Pendidikan Dan Studi Islam 4, no. 2, Sept (2018): 44-53. https://doi.org/https://doi.org/10.31943/jurnal_risalah.v4i2.63.

Thabrani, Abdul Muis. Pengantar \& Dimensi-Dimensi Pendidikan. Jember: STAIN Jember Press, 2013.

Tilaar, Henry Alexis Rudolf. Pendidikan, Kebudayaan, Dan Masyarakat Madani Indonesia. Bandung: PT. Remaja Rosdakarya, 1999.

Truna, Dody S, Abdul Syukur, Husnul Qodim, and Ahmad Soheh Mukarom. "Pendidikan Multikultural Sebagai Upaya Pencegahan Radikalisme Di Indonesia." Digital Library UIN Sunan Gunung Djati Bandung, 2020.

Waston, C.W. Multiculturalism. London: Open University Press, 2000.

Wenda, Nusen, Johannis Kaawoan, and Neni Kumayas. "Peran Kepala Suku Dani Dalam Menyelesaikan Konflik Di Kampung Wulukubun Arso 14 Distrik Skanto Kabupaten Keerom Provinsi Papua.” JURNAL EKSEKUTIF 1, no. 1 (2017).

Zulfa, Eva Achjani. "Bali Nuraga-Lampung: Identity Conflict Behind the Policy." Indonesian J. Int'l L. 11 (2013): 261. 